This is an electronic reprint of the original article. This reprint may differ from the original in pagination and typographic detail.

Author(s): Ryazantsev, Sergey V.; Lundell, Jan; Feldman, Vladimir I.; Khriachtchev, Leonid

Title: $\quad$ Photochemistry of the $\mathrm{H} 2 \mathrm{O} / \mathrm{CO}$ System Revisited : The HXeOH $\cdots$ CO Complex in a Xenon Matrix

Year: $\quad 2018$

Version:

Please cite the original version:

Ryazantsev, S. V., Lundell, J., Feldman, V. I., \& Khriachtchev, L. (2018).

Photochemistry of the $\mathrm{H} 2 \mathrm{O} / \mathrm{CO}$ System Revisited : The $\mathrm{HXeOH} \cdots \mathrm{CO}$ Complex in a

Xenon Matrix. Journal of Physical Chemistry C, 122(1), 159-166.

https://doi.org/10.1021/acs.jpca.7b10293

All material supplied via JYX is protected by copyright and other intellectual property rights, and duplication or sale of all or part of any of the repository collections is not permitted, except that material may be duplicated by you for your research use or educational purposes in electronic or print form. You must obtain permission for any other use. Electronic or print copies may not be offered, whether for sale or otherwise to anyone who is not an authorised user. 


\section{Article}

Subscriber access provided by JYVASKYLAN UNIV

\section{Photochemistry of the HO/CO System Revisited: The HXeOH....CO Complex in a Xenon Matrix}

Sergey V. Ryazantsev, Jan Lundell, Vladimir I. Feldman, and Leonid Khriachtchev

J. Phys. Chem. A, Just Accepted Manuscript • DOI: 10.1021/acs.jpca.7b10293 • Publication Date (Web): 05 Dec 2017

Downloaded from http://pubs.acs.org on December 7, 2017

\section{Just Accepted}

"Just Accepted" manuscripts have been peer-reviewed and accepted for publication. They are posted online prior to technical editing, formatting for publication and author proofing. The American Chemical Society provides "Just Accepted" as a free service to the research community to expedite the dissemination of scientific material as soon as possible after acceptance. "Just Accepted" manuscripts appear in full in PDF format accompanied by an HTML abstract. "Just Accepted" manuscripts have been fully peer reviewed, but should not be considered the official version of record. They are accessible to all readers and citable by the Digital Object Identifier (DOI®). "Just Accepted" is an optional service offered to authors. Therefore, the "Just Accepted" Web site may not include all articles that will be published in the journal. After a manuscript is technically edited and formatted, it will be removed from the "Just Accepted" Web site and published as an ASAP article. Note that technical editing may introduce minor changes to the manuscript text and/or graphics which could affect content, and all legal disclaimers and ethical guidelines that apply to the journal pertain. ACS cannot be held responsible for errors or consequences arising from the use of information contained in these "Just Accepted" manuscripts. 


\title{
Photochemistry of the $\mathrm{H}_{2} \mathrm{O} / \mathrm{CO}$ System Revisited: The $\mathrm{HXeOH} \cdots \mathrm{CO}$ Complex in a Xenon Matrix
}

\author{
Sergey V. Ryazantsev, ${ }^{a, b}$ Jan Lundell, ${ }^{c}$ Vladimir I. Feldman, ${ }^{b}$ and Leonid Khriachtchev ${ }^{a, *}$ \\ ${ }^{a}$ Department of Chemistry, University of Helsinki, P. O. Box 55, FI-00014 Helsinki, Finland \\ ${ }^{\mathrm{b}}$ Department of Chemistry, Lomonosov Moscow State University, Moscow 119991 Russia \\ ${ }^{\mathrm{c}}$ Department of Chemistry, University of Jyväskylä, Jyväskylä, FI-40014, Finland
}

\begin{abstract}
:
We report on the complex of a noble-gas hydride $\mathrm{HXeOH}$ with carbon monoxide. This species is prepared via the annealing-induced $\mathrm{H}+\mathrm{Xe}+\mathrm{OH} \cdots \mathrm{CO}$ reaction in a xenon matrix, the $\mathrm{OH} \cdots \mathrm{CO}$ complexes being produced by VUV photolysis of the $\mathrm{H}_{2} \mathrm{O} \cdots \mathrm{CO}$ complexes. The $\mathrm{H}-\mathrm{Xe}$ stretching mode of the $\mathrm{HXeOH} \cdots \mathrm{CO}$ complex absorbs at $1590.3 \mathrm{~cm}^{-1}$ and it is blue-shifted by $12.7 \mathrm{~cm}^{-1}$ from the $\mathrm{H}-\mathrm{Xe}$ stretching band of $\mathrm{HXeOH}$ monomer. The observed blue shift indicates the stabilization of the $\mathrm{H}-\mathrm{Xe}$ bond upon complexation, which is characteristic of complexes of noble-gas hydrides. The $\mathrm{HXeOH} \cdots \mathrm{CO}$ species is the first complex of a noble-gas hydride with carbon monoxide and the second observed complex of $\mathrm{HXeOH}$. Based on the MP2/aug-cc-pVTZ-PP calculations, the experimental complex is assigned to the structure, where the carbon atom of $\mathrm{CO}$ interacts with the oxygen atom of $\mathrm{HXeOH}$.
\end{abstract}




\section{INTRODUCTION}

Experimental noble-gas chemistry was ignited by the discovery of xenon hexafluoroplatinate by

Neil Bartlett in $1962 .{ }^{1}$ A large number of noble-gas compounds were reported later. ${ }^{2-5}$ Matrix isolation technique has played an important role from the beginning of noble-gas chemistry. ${ }^{6,7}$ One interesting part of these studies is constituted by noble-gas hydrides with the general formula $\mathrm{HNgY}$ where $\mathrm{Ng}$ is a noble-gas atom and $\mathrm{Y}$ is an electronegative atom or fragment. ${ }^{4,8,9}$ These exotic molecules are characterized by a charge-transfer character $(\mathrm{HNg})^{+} \mathrm{Y}^{-}$and a strong $\mathrm{H}-\mathrm{Ng}$ stretching absorption. About 30 noble-gas hydrides have been reported to date, including an argon molecule $\mathrm{HArF},{ }^{10,11}$ an organic krypton molecule $\mathrm{HKrCCH}^{12}$ and the most recent additions to this family $\mathrm{HKrCCCl}, \mathrm{HXeCCCl}$, and $\mathrm{C}_{6} \mathrm{H}_{5} \mathrm{CCXeH} .{ }^{13,14}$ Importantly for the present work, $\mathrm{HXeOH}$ was prepared by insertion of a xenon atom into water. ${ }^{15}$ Noble-gas hydrides are usually prepared in lowtemperature solid matrices by photolysis (or radiolysis) of the HY precursor and subsequent annealing to mobilize the hydrogen atoms and promote the $\mathrm{H}+\mathrm{Ng}+\mathrm{Y}$ reaction. In some cases, these molecules appear directly after UV photolysis of HY/Ng matrices. ${ }^{10,16,17}$

Matrix isolation is a powerful tool to study non-covalent interactions, in particular, those involving noble-gas hydrides. ${ }^{18,19}$ Due to the relatively weak bonding and large dipole moments, the HNgY molecules can be strongly affected by the interaction with other species. As an interesting feature, these complexes are usually characterized by blue shifts of the $\mathrm{H}-\mathrm{Ng}$ stretching mode, which means stabilization of the $\mathrm{H}-\mathrm{Ng}$ chemical bond. For example, the $\mathrm{H}-\mathrm{Xe}$ stretching mode of the $\mathrm{HXeOH} \cdots \mathrm{H}_{2} \mathrm{O}$ and $\mathrm{HXeBr} \cdots \mathrm{HBr}$ complexes in a xenon matrix exhibits large shifts of +103 and up to ca. $+150 \mathrm{~cm}^{-1}$ from that of the corresponding monomers, respectively. ${ }^{20,21}$ The largest shift (ca. $+300 \mathrm{~cm}^{-1}$ ) has been reported for the $\mathrm{HKrCl} \cdots \mathrm{HCl}$ complex in a krypton matrix. ${ }^{22}$ On the other hand, there are examples of the weaker complexes with relatively small shifts, such as the $\mathrm{HXeBr} \cdots \mathrm{N}_{2}\left(+11.5\right.$ and $\left.+16 \mathrm{~cm}^{-1}\right)$ and $\mathrm{HXeCCH} \cdots \mathrm{HCCH}\left(\right.$ from +19 to $\left.+28 \mathrm{~cm}^{-1}\right)$ complexes 
studied in a xenon matrix..$^{23,24}$ The number of computational works on complexes of noble-gas hydrides is substantial (see, for example, Refs. 25-39).

The aim of this work is to prepare and identify the $\mathrm{HXeOH} \cdots \mathrm{CO}$ complex, the first complex between a noble-gas hydride and carbon monoxide. The preparation of $\mathrm{HXeY} \cdots \mathrm{CO}$ complexes is not an easy task. In the general procedure, one has to start from the HY $\cdots \mathrm{CO}$ complex in a matrix and photolyze it to produce the $\mathrm{Y} \cdots \mathrm{CO}$ complex. The obstacle here is the probable reaction of carbon monoxide with the $\mathrm{Y}$ radical $(\mathrm{OH}$ in the present case). However, we have recently demonstrated that the $\mathrm{OH} \cdots \mathrm{CO}$ complex can be prepared and stabilized at low temperatures in noble-gas matrices, particularly in a xenon matrix. ${ }^{40}$ The approach is based on a two-step photolysis of a $\mathrm{HCOOH} / \mathrm{Ng}$ matrix: first with UV light to produce the $\mathrm{H}_{2} \mathrm{O} \cdots \mathrm{CO}$ complexes and then with VUV light to generate the $\mathrm{OH} \cdots \mathrm{CO}$ complexes (in general, together with hydrocarboxyl radicals, $\mathrm{HOCO})$. It has been found that the units of the $\mathrm{OH} \cdots \mathrm{CO}$ complex react at about $30 \mathrm{~K}$ and produce trans-HOCO. This reaction is a problem for the present target because thermal mobility of hydrogen atoms in a xenon matrix mainly occurs above $35 \mathrm{~K} .{ }^{41,42}$ However, there is a chance that some hydrogen atoms can still react with the $\mathrm{Xe}-\mathrm{OH} \cdots \mathrm{CO}$ centers before decomposition of the $\mathrm{OH} \cdots \mathrm{CO}$ complexes. In this work, the largest amount of the $\mathrm{OH} \cdots \mathrm{CO}$ complexes is achieved by direct deposition of $\mathrm{H}_{2} \mathrm{O} / \mathrm{CO} / \mathrm{Xe}$ matrices and VUV photolysis (without the use of formic acid). The experiments are supported by quantum chemical calculations at the MP2/aug-cc-pVTZ-PP level of theory.

\section{EXPERIMENTAL DETAILS AND RESULTS}

Experimental details The $\mathrm{HCOOH} / \mathrm{Xe}, \mathrm{H}_{2} \mathrm{O} / \mathrm{CO} / \mathrm{Xe}$, and $\mathrm{H}_{2} \mathrm{O} / \mathrm{Xe}$ mixtures were made in a glass bulb by using standard manometric procedures. $\mathrm{HCOOH} \mathrm{(Merck,}>98 \%$ ) was degassed by several freeze-pump-thaw cycles. Xenon (Linde, 99.999\%) and carbon monoxide (AGA, 99.95\%) were 
used as purchased. Distilled water was deionized prior the sample preparation. Since formic acid and water are easily adsorbed on glass surfaces, the bulb was passivated with these vapors by several fill-keep-evacuate cycles prior to the mixture preparation. The matrices were deposited onto a CsI window cooled by a closed-cycle helium cryostat (RDK-408D2, SHI). The best results were obtained for deposition of matrices at $30 \mathrm{~K}$. The $\mathrm{HCOOH} / \mathrm{Xe}$ matrices were photolyzed at $4.3 \mathrm{~K}$ by 250-nm light $\left(10 \mathrm{~Hz}, \sim 5 \mathrm{~mJ} \mathrm{~cm}^{-2}\right)$ of an optical parametric oscillator (OPO, Sunlite, Continuum). After UV photodecomposition of formic acid, the matrices were exposed to VUV light (130-170 $\mathrm{nm}$ ) of a Kr lamp (Opthos) using electric power of $\sim 30 \mathrm{~W}$. The $\mathrm{H}_{2} \mathrm{O} / \mathrm{CO} / \mathrm{Xe}$ and $\mathrm{H}_{2} \mathrm{O} / \mathrm{Xe}$ matrices were photolyzed only by the VUV light. The IR absorption spectra in the $4000-600 \mathrm{~cm}^{-1}$ range were measured at $4.3 \mathrm{~K}$ with an FTIR spectrometer (Vertex 80, Bruker) using $1 \mathrm{~cm}^{-1}$ resolution and 500 scans.

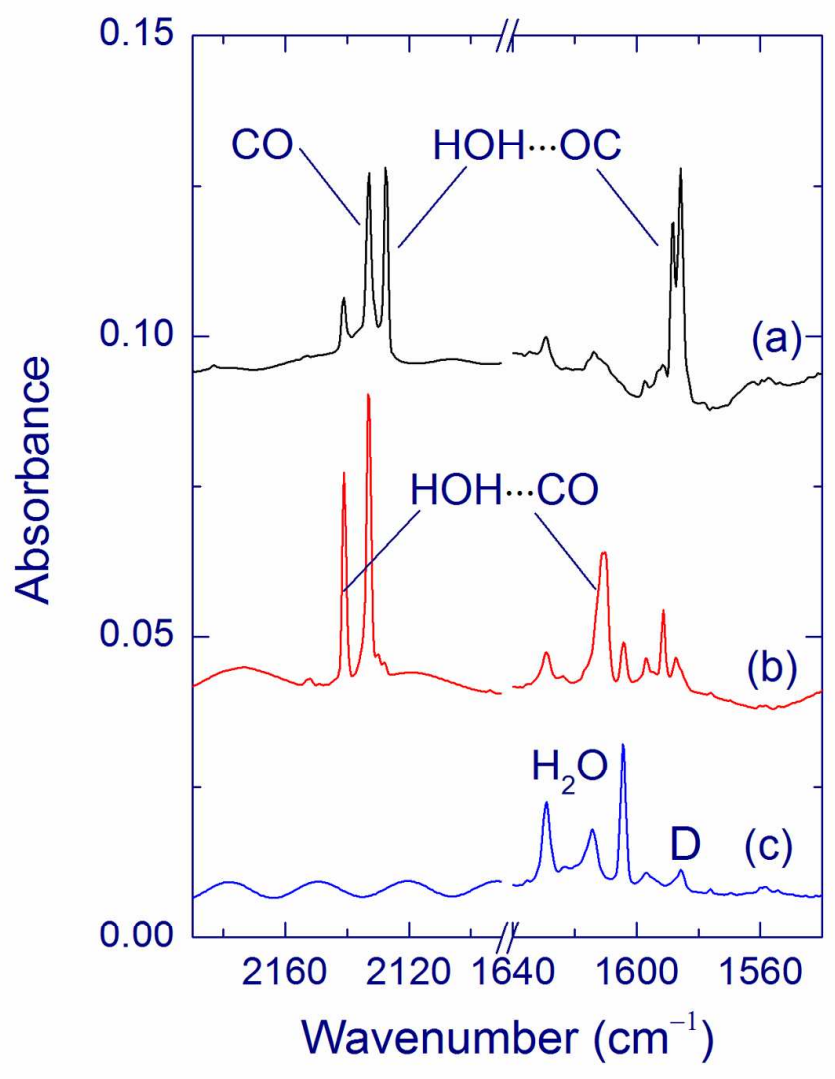


Figure 1. FTIR spectra showing (a) the $\mathrm{H}_{2} \mathrm{O} \cdots \mathrm{CO}$ complexes prepared by 250 -nm photolysis and annealing at $45 \mathrm{~K}$ of a $\mathrm{HCOOH} / \mathrm{Xe}(1 / 1000)$ matrix; (b) the $\mathrm{H}_{2} \mathrm{O} \cdots \mathrm{CO}$ complexes prepared by codeposition of $\mathrm{H}_{2} \mathrm{O}$ and $\mathrm{CO}$ in excess of xenon $\left(\mathrm{H}_{2} \mathrm{O} / \mathrm{CO} / \mathrm{Xe}=1 / 1 / 1000\right)$; (c) a reference spectrum of a $\mathrm{H}_{2} \mathrm{O} / \mathrm{Xe}(1 / 1000)$ matrix (without $\mathrm{CO}$ ). The water dimer band is marked in spectrum c by $\mathrm{D}$.

Experimental results UV photolysis of formic acid in noble-gas matrices leads to large amounts of the $\mathrm{H}_{2} \mathrm{O} \cdots \mathrm{CO}$ complexes. ${ }^{43} \mathrm{H}_{2} \mathrm{O}$ and $\mathrm{CO}$ monomers and $\mathrm{CO}_{2}$ (possibly complexed with $\mathrm{H}_{2}$ ) are also produced in some amounts. In a xenon matrix, the $\mathrm{H}_{2} \mathrm{O} \cdots \mathrm{CO}$ complexes obtained by $250-\mathrm{nm}$ photolysis of formic acid mainly have the structure $\mathrm{HOH} \cdots \mathrm{OC}$ where a hydrogen atom of water interacts with the oxygen atom of carbon monoxide (spectrum a in Figure 1). In this structure, the CO stretching mode is red-shifted from that of CO monomer $\left(2133.0 \mathrm{~cm}^{-1}\right)$. Annealing of the photolyzed matrix at $45 \mathrm{~K}$ increases the amount of the second structure $\mathrm{HOH} \cdots \mathrm{CO}$ where a hydrogen atom of water interacts with the carbon atom of carbon monoxide; however, the $\mathrm{HOH} \cdots \mathrm{OC}$ structure still dominates. In the $\mathrm{HOH}^{\cdots} \mathrm{CO}$ structure, the $\mathrm{CO}$ stretching mode is blueshifted from that of $\mathrm{CO}$ monomer. To recall, after photolysis of formic acid in neon, argon, and krypton matrices, the $\mathrm{HOH} \cdots \mathrm{CO}$ structure dominates, which is in contrast to a xenon matrix, and this difference is unclear.

Deposition of an $\mathrm{H}_{2} \mathrm{O} / \mathrm{CO} / \mathrm{Xe}$ mixture also produces the $\mathrm{H}_{2} \mathrm{O} \cdots \mathrm{CO}$ complexes in a xenon matrix, in addition to $\mathrm{H}_{2} \mathrm{O}$ and $\mathrm{CO}$ monomers (spectrum $\mathrm{b}$ in Figure 1). Interestingly, the $\mathrm{HOH} \cdots \mathrm{CO}$ structure dominates in this case, in contrast to the situation with UV photolysis of formic acid. The strongest bands of the $\mathrm{H}_{2} \mathrm{O} \cdots \mathrm{CO}$ complex prepared by these two methods are given in Table 1 . These results are in a reasonable agreement with the calculations: ${ }^{43} v(\mathrm{CO})$ and $v_{2}\left(\mathrm{H}_{2} \mathrm{O}\right)$ are higher for the $\mathrm{HOH} \cdots \mathrm{CO}$ structure whereas the water stretching frequencies are higher for the $\mathrm{HOH} \cdots \mathrm{OC}$ 
structure. Spectrum c in Figure 1 shows a reference spectrum of a $\mathrm{H}_{2} \mathrm{O} / \mathrm{Xe}$ matrix mainly with water monomers.

Table 1. Main bands (frequencies in $\mathrm{cm}^{-1}$ ) of the $\mathrm{H}_{2} \mathrm{O} \cdots \mathrm{CO}$ complex observed in a xenon matrix after UV photolysis of formic acid and annealing at $45 \mathrm{~K}$ versus co-deposition of $\mathrm{H}_{2} \mathrm{O}$ and $\mathrm{CO}$.

\begin{tabular}{|c|c|c|}
\hline Mode & $\begin{array}{c}\text { Photolysis of } \mathrm{HCOOH} \\
\qquad \mathrm{HOH} \cdots \mathrm{OC}\end{array}$ & $\begin{array}{c}\text { Co-deposition of } \mathrm{H}_{2} \mathrm{O} \text { and } \mathrm{CO} \\
\mathrm{HOH} \cdots \mathrm{CO}\end{array}$ \\
\hline$v_{3}\left(\mathrm{H}_{2} \mathrm{O}\right)$ & $\begin{array}{l}3716.5 \\
3715.0 \\
3712.9\end{array}$ & 3710.3 \\
\hline$v_{1}\left(\mathrm{H}_{2} \mathrm{O}\right)$ & $\begin{array}{l}3628.9 \\
3623.1\end{array}$ & 3616.2 \\
\hline$v(\mathrm{CO})$ & 2127.5 & 2140.9 \\
\hline$v_{2}\left(\mathrm{H}_{2} \mathrm{O}\right)$ & $\begin{array}{l}1588.1 \\
1585.6\end{array}$ & 1610.6 \\
\hline
\end{tabular}




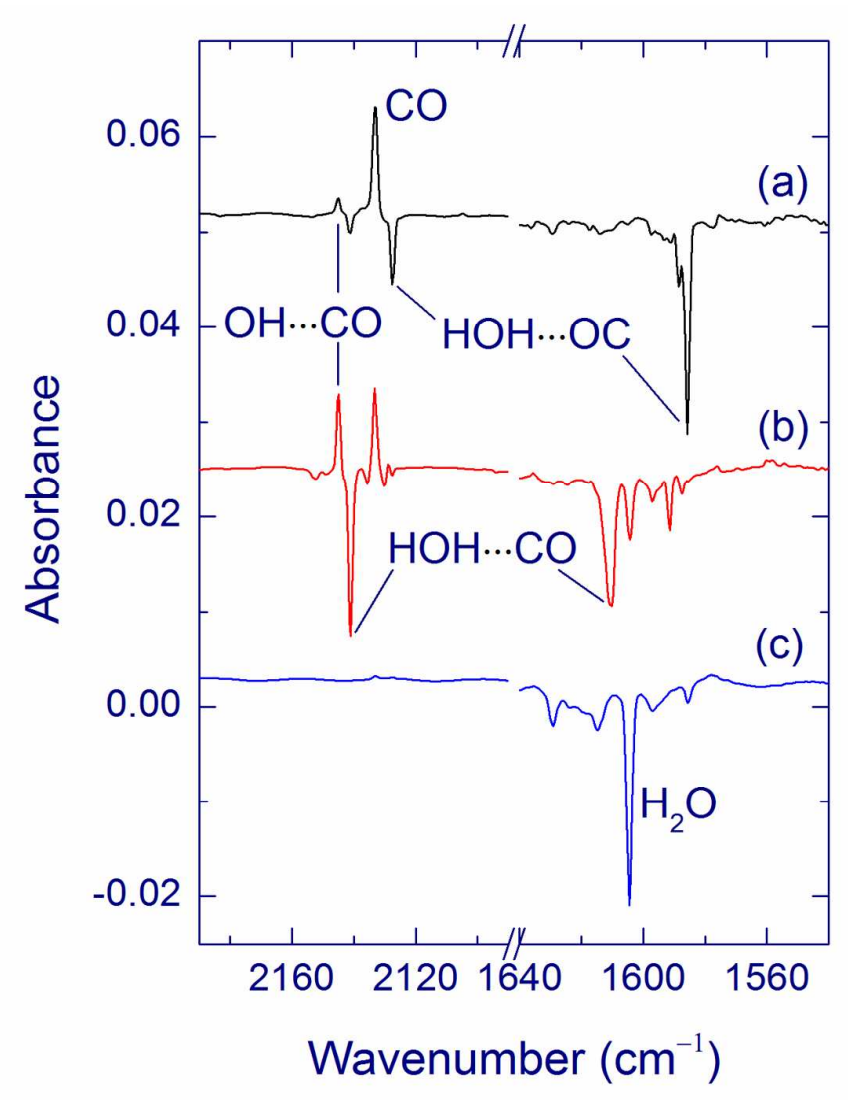

Figure 2. Difference FTIR spectra showing the results of VUV photolysis of (a) UV-photolyzed and annealed $\mathrm{HCOOH} / \mathrm{Xe}$ matrix (spectrum a in Figure 1); (b) $\mathrm{H}_{2} \mathrm{O} / \mathrm{CO} / \mathrm{Xe}$ matrix (spectrum b in Figure 1); (c) $\mathrm{H}_{2} \mathrm{O} / \mathrm{Xe}$ matrix (spectrum c in Figure 1).

VUV light decomposes water molecules in a xenon matrix. VUV photolysis of the $\mathrm{H}_{2} \mathrm{O} \cdots \mathrm{CO}$ complex can produce the $\mathrm{OH} \cdots \mathrm{CO}$ complex and trans-HOCO radical. ${ }^{40}$ For the $\mathrm{H}_{2} \mathrm{O} \cdots \mathrm{CO}$ complex prepared from formic acid (spectrum a in Figure 2), the amount of the $\mathrm{OH} \cdots \mathrm{CO}$ complex (with bands at 3520.0 and $2145.0 \mathrm{~cm}^{-1}$ ) is rather small whereas trans-HOCO (with a characteristic band at $1834.4 \mathrm{~cm}^{-1}$ ) is produced in substantial amounts. ${ }^{40}$ For VUV photolysis of the co-deposited $\mathrm{H}_{2} \mathrm{O} / \mathrm{CO} / \mathrm{Xe}$ matrix, the amount of the $\mathrm{OH} \cdots \mathrm{CO}$ complex substantially increases (spectrum $\mathrm{b}$ in Figure 2), whereas the formation of trans-HOCO becomes less efficient. These results confirm our 
recent hypothesis that the $\mathrm{OH} \cdots \mathrm{CO}$ complex is produced preferentially from the $\mathrm{HOH} \cdots \mathrm{CO}$ structure rather than from the $\mathrm{HOH} \cdots \mathrm{OC}$ structure. ${ }^{40}$ The amounts of $\mathrm{CO}$ monomers and $\mathrm{CO}_{2}$ (possibly complexed with $\mathrm{H}_{2}$ ) increase upon VUV photolysis in both cases. The $\mathrm{OH}^{\cdots} \mathrm{CO}$ bands are evidently absent after photolysis of the $\mathrm{H}_{2} \mathrm{O}$ /Xe matrix (spectrum c in Figure 2). In this case, the OH radical $\left(3531.2 \mathrm{~cm}^{-1}\right)$ and the $\mathrm{OH} \cdots \mathrm{H}_{2} \mathrm{O}$ complex $\left(3402 \mathrm{~cm}^{-1}\right)$ are observed, originating from photolysis of water monomers and dimers, respectively. ${ }^{20}$ In all these matrices, the progression of the $(\mathrm{XeHXe})^{+}$bands with the main component at $730.5 \mathrm{~cm}^{-1}$ appears after VUV photolysis. ${ }^{44}$

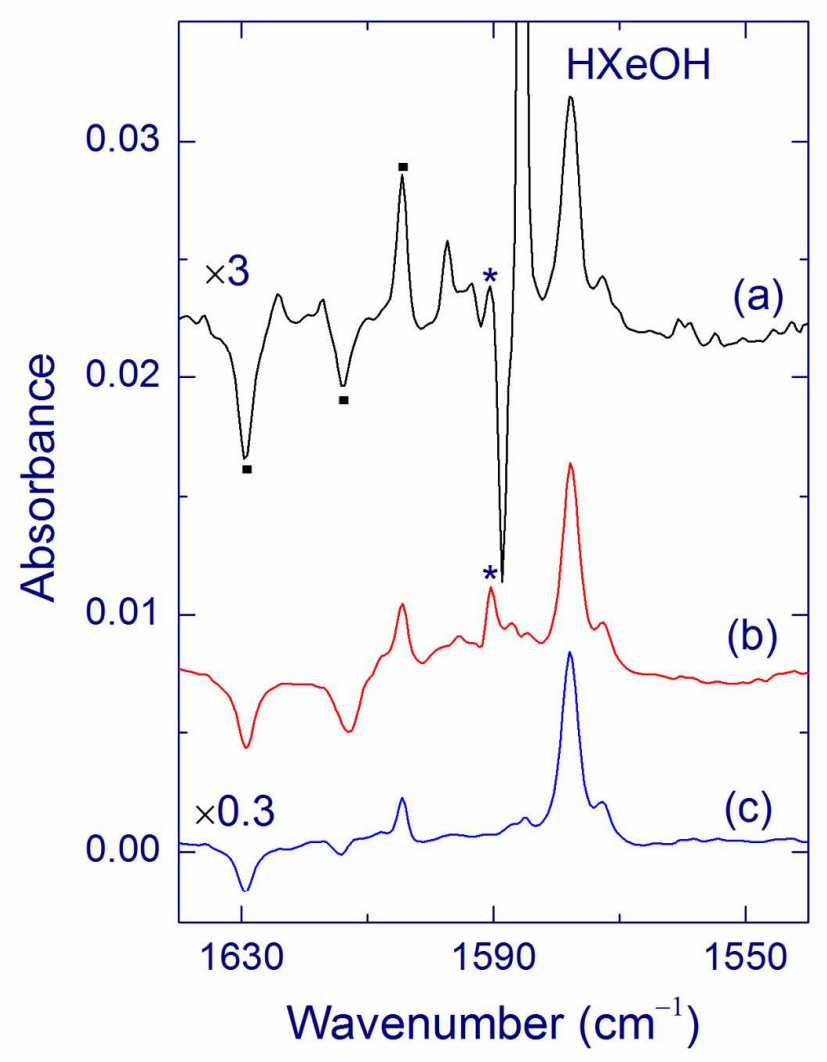

Figure 3. Difference FTIR spectra showing the results of annealing at $45 \mathrm{~K}$ of VUV-photolyzed (a) UV-photolyzed and annealed $\mathrm{HCOOH} / \mathrm{Xe}$ matrix (spectrum a in Figure 2); (b) $\mathrm{H}_{2} \mathrm{O} / \mathrm{CO} / \mathrm{Xe}$ matrix (spectrum b in Figure 2); (c) $\mathrm{H}_{2} \mathrm{O} / \mathrm{Xe}$ matrix (spectrum c in Figure 2). The intensities of the $\mathrm{HXeOH}$ bands are equalized for better presentation using the multiplication factors shown for spectra a and c. The bands of monomeric water are marked in trace a with dots. The $1590.3 \mathrm{~cm}^{-1}$ band assigned to 
the $\mathrm{HXeOH} \cdots \mathrm{CO}$ complex is marked with an asterisk. The negative band at $1588.1 \mathrm{~cm}^{-1}$ seen in spectrum a belongs to the $\mathrm{H}_{2} \mathrm{O} \cdots \mathrm{CO}$ complex (Table 1).

VUV photolysis of water produces hydrogen atoms in the matrix. In solid xenon, hydrogen atoms are thermally mobilized above $\sim 35 \mathrm{~K} .{ }^{41,42}$ The mobile hydrogen atoms participate in different reactions. In matrices containing $\mathrm{CO}$ and $\mathrm{H}_{2} \mathrm{O}$, the formation of $\mathrm{HCO}(2442.4,1856.6$, and 1076.2 $\left.\mathrm{cm}^{-1}\right)$ and $\mathrm{HCO} \cdots \mathrm{H}_{2} \mathrm{O}\left(3710.4,3707.5,2516.4,2510.7,1850.0,1847.6,1092.8\right.$, and $\left.1090.8 \mathrm{~cm}^{-1}\right)$ is observed. ${ }^{40,45}$ In matrices containing residual $\mathrm{HCOOH}$, trace amounts of trans $-\mathrm{H}_{2} \mathrm{COOH}$ are found after annealing $\left(959.6\right.$ and $\left.957.8 \mathrm{~cm}^{-1}\right)$ due to the $\mathrm{HCOOH}+\mathrm{H}$ reaction. ${ }^{46}$ In addition, the $\mathrm{H}-\mathrm{Xe}$ stretching bands of a number of noble-gas hydrides appear in all three types of matrices: $\mathrm{HXeOH}\left(1577.6 \mathrm{~cm}^{-1}\right),{ }^{15} \mathrm{HXeO}\left(1466.1 \mathrm{~cm}^{-1}\right),{ }^{47} \mathrm{HXeOXeH}\left(1379.7 \mathrm{~cm}^{-1}\right),{ }^{48}$ and $\mathrm{HXeH}(1165.9$ and $\left.1180.6 \mathrm{~cm}^{-1}\right) .{ }^{49}$ Annealing at 35-45 K efficiently decomposes the $\mathrm{OH} \cdots \mathrm{CO}$ complex, producing trans-HOCO, in agreement with the previous data. ${ }^{40}$ In the matrices containing (prior annealing) the $\mathrm{OH} \cdots \mathrm{CO}$ complexes (spectra a and b in Figure 3), annealing produces a relatively weak band at $1590.3 \mathrm{~cm}^{-1}$. This band is blue-shifted by $12.7 \mathrm{~cm}^{-1}$ from the $\mathrm{H}-\mathrm{Xe}$ stretching band of $\mathrm{HXeOH}$ monomer, and it is assigned in this work to the $\mathrm{H}-\mathrm{Xe}$ stretching mode of the $\mathrm{HXeOH} \cdots \mathrm{CO}$ complex. This band is absent after photolysis and annealing of $\mathrm{H}_{2} \mathrm{O} / \mathrm{Xe}$ matrices (spectrum $\mathrm{c}$ in Figure 3). Other absorptions of the $\mathrm{HXeOH} \cdots \mathrm{CO}$ complex are not observed due to their relative weakness. As seen in Figure 3, some redistribution of intensities of the water monomer bands occurs upon annealing. 


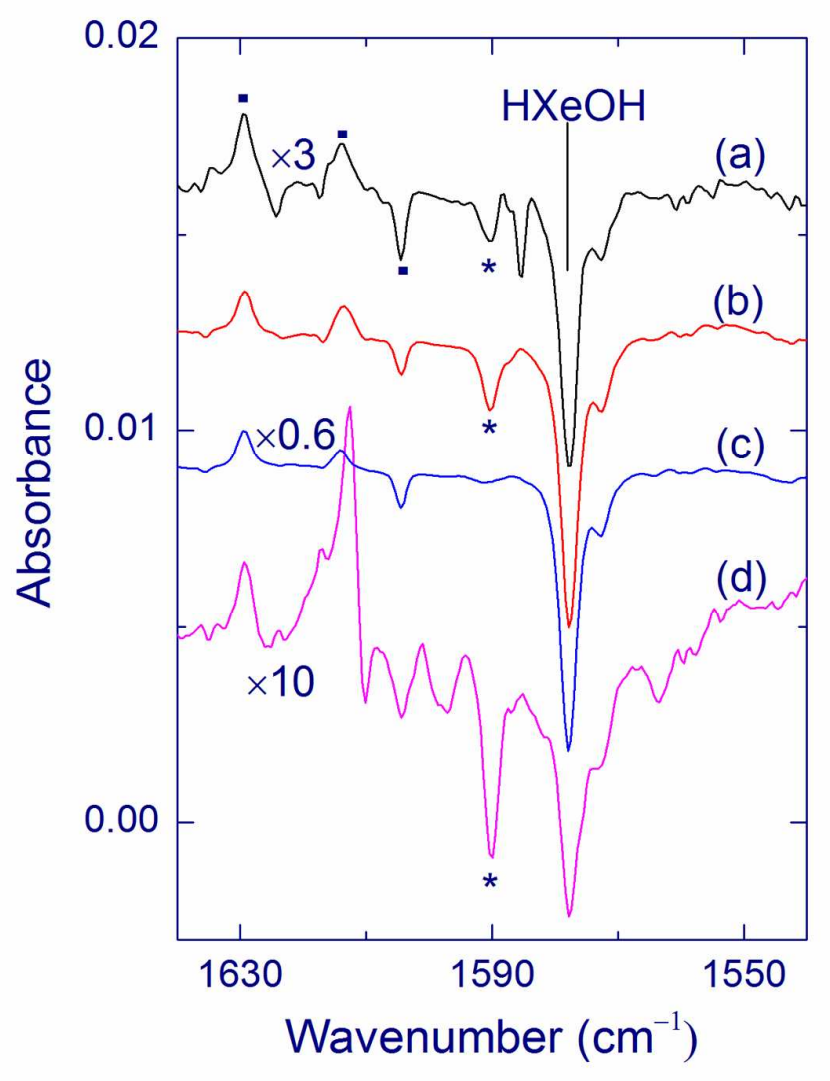

Figure 4. Difference FTIR spectra showing the results of 254-nm irradiation of VUV-photolyzed and annealed at $45 \mathrm{~K}$ (a) UV-photolyzed and annealed $\mathrm{HCOOH} / \mathrm{Xe}$ matrix (spectrum a in Figure 3);

(b) $\mathrm{H}_{2} \mathrm{O} / \mathrm{CO} / \mathrm{Xe}$ matrix (spectrum b in Figure 3); (c) $\mathrm{H}_{2} \mathrm{O} / \mathrm{Xe}$ matrix (spectrum c in Figure 3).

Spectrum d shows the results of 254-nm irradiation of a VUV-photolyzed and annealed at $27 \mathrm{~K}$ $\mathrm{H}_{2} \mathrm{O} / \mathrm{CO} / \mathrm{Xe}$ matrix (similar to spectrum $\mathrm{b}$ in Figure 3). The intensities of the $\mathrm{HXeOH}$ bands are equalized for better presentation using the multiplication factors shown for spectra a, c, and d. Spectrum c presents decomposition of a half of $\mathrm{HXeOH}$ prepared by annealing (spectrum $\mathrm{c}$ in Figure 3). The bands of monomeric water are marked in trace a with dots. The band assigned to the $\mathrm{HXeOH} \cdots \mathrm{CO}$ complex is marked with an asterisk. 
Noble-gas hydrides are photolabile species and their photodecomposition helps the identification of relatively weak bands of their complexes. ${ }^{20-22,50,51}$ In the present work, a low-pressure mercury lamp (254 nm) was used to decompose the noble-gas hydrides. For matrices containing both $\mathrm{H}_{2} \mathrm{O}$ and $\mathrm{CO}$, the $1590.3 \mathrm{~cm}^{-1}$ band of the $\mathrm{HXeOH}^{\cdots} \mathrm{CO}$ complex decreases in intensity synchronously with the band of $\mathrm{HXeOH}$ monomer (spectra a and $\mathrm{b}$ in Figure 4). For the $\mathrm{H}_{2} \mathrm{O} / \mathrm{Xe}$ matrix, this band does not appear in the decomposition spectrum (spectrum $\mathrm{c}$ in Figure 4). Other xenon hydrides ( $\mathrm{HXeO}, \mathrm{HXeOXeH}$, and $\mathrm{HXeH}$ ) are also decomposed by 254-nm light with different efficiencies. As seen in Figure 4, some redistribution of intensities of the water monomer bands occurs at low temperature (even in the dark), and this redistribution is opposite to that produced by annealing (Figure 3). Spectrum d represents the result of 254-nm irradiation of a $\mathrm{H}_{2} \mathrm{O} / \mathrm{CO} / \mathrm{Xe}$ matrix annealed at $27 \mathrm{~K}$ (after VUV photolysis). In this case, the bands of $\mathrm{HXeOH}$ and $\mathrm{HXeOH} \cdots \mathrm{CO}$ have similar intensities but they are substantially weaker than after annealing at $45 \mathrm{~K}$.

\section{COMPUTATIONAL DETAILS AND RESULTS}

Computational details All ab initio calculations in this work were performed in the framework of GAUSSIAN electronic structure program. ${ }^{52}$ Electron correlation was considered via Møller-Plesset perturbation theory to second order (MP2). ${ }^{53,54}$ For xenon, the relativistic effective core potential aug-cc-pVTZ-PP basis set ${ }^{55}$ was used as retrieved from the EMSL Basis Set Exchange database. ${ }^{56}$ For oxygen, carbon, and hydrogen, the Dunning augmented triple-zeta basis set aug-cc-pVTZ was used. $^{57,58}$

The Mulliken charges, natural population analysis, ${ }^{59}$ as well as anharmonic vibrational frequencies and intensities computed according to the method of Barone, ${ }^{60,61}$ were all acquired as implemented in the GAUSSIAN. 
The interaction energy was obtained as a difference of the total energy between the complex and the monomers at an infinite distance, where the monomer wavefunctions were derived in the dimer centered basis set. This approach corresponds to the counterpoise correction proposed by Boys and Bernardi aimed to minimize the basis set superposition error (BSSE). ${ }^{62}$

Computational results The calculations predict six structures of the $\mathrm{HXeOH} \cdots \mathrm{CO}$ complex (see Figure 5 and Table 2). The atomic partial charges, harmonic spectra, and harmonic and anharmonic shifts are given in Tables 3, 4, and 5, respectively. The atomic coordinates and the full anharmonic spectra of the monomers and complex structures are presented in the Supplementary Material.

In two structures (I and II), carbon monoxide interacts with the hydrogen atom of the $\mathrm{OH}$ group of $\mathrm{HXeOH}$ via the carbon and oxygen atoms, respectively (hydrogen bond lengths of 2.39 and 2.16 $\AA ̊$ ). Structure I is significantly stronger than structure II (interaction energies -5.17 and $-3.19 \mathrm{~kJ}$ $\mathrm{mol}^{-1}$ after BSSE correction). The H-Xe stretching mode of these two structures is red-shifted (harmonic shift -23.3 and $-7.4 \mathrm{~cm}^{-1}$ ), which is an unusual case for complexes of noble-gas hydrides, where a blue-shift of this mode is the normal effect. ${ }^{18}$ Previously, the HArF $\cdots \mathrm{P}_{2}$ and $\mathrm{HXeBr} \cdots \mathrm{Xe}$ (one structure) complexes have been predicted to have red shifts of the $\mathrm{H}-\mathrm{Ng}$ stretching mode. ${ }^{26,63}$ The red shifts of the H-Xe stretching mode in structures I and II are connected with the decrease of the positive charge on the HXe group (NPA: by 0.008 and 0.001 elementary charges). The absolute values of the anharmonic shifts are smaller as in fact, for all obtained structures.

In two structures (III and IV), carbon monoxide interacts with the oxygen atom of the $\mathrm{OH}$ group of $\mathrm{HXeOH}$ via the carbon and oxygen atoms, respectively (van der Waals bond lengths of 2.87 and $3.02 \AA$ ). Structure III is stronger than structure IV (interaction energies -9.20 and $-6.75 \mathrm{~kJ} \mathrm{~mol}^{-1}$ after BSSE correction), and these two structures show the strongest interaction among the found ones. The H-Xe stretching mode of these two structures shows small blue shifts (harmonic shifts 
+9.8 and $+7.5 \mathrm{~cm}^{-1}$ ), which is the normal effect for complexes of $\mathrm{HNgY}$ molecules. The blue shifts of the $\mathrm{H}-\mathrm{Xe}$ stretching mode in these structures are connected with the increase of the positive charge on the HXe group (NPA: both by 0.010 elementary charges).

In two structures (V and VI), carbon monoxide interacts with the hydrogen atom of the HXe group via the carbon and oxygen atoms, respectively (hydrogen bond lengths of 2.84 and $2.77 \AA$ ). These two structures show the weakest interaction among the found ones (interaction energies -2.66 and $-1.00 \mathrm{~kJ} \mathrm{~mol}^{-1}$ after BSSE correction). The $\mathrm{H}-\mathrm{Xe}$ stretching mode of these two structures shows moderate blue shift $\left(+41.8\right.$ and $\left.+24.2 \mathrm{~cm}^{-1}\right)$, in a general agreement with the increase of the positive charge on the HXe group (NPA: by 0.011 and 0.009$)$.

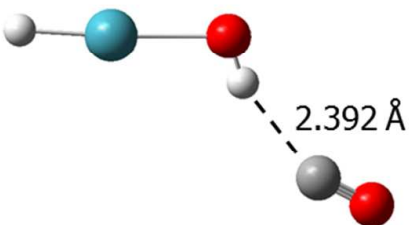

I

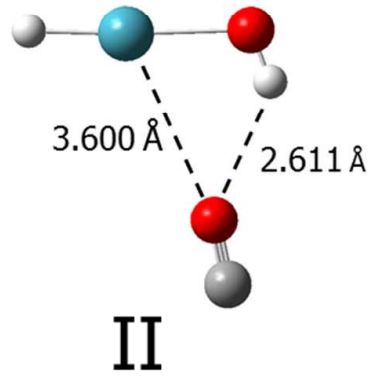

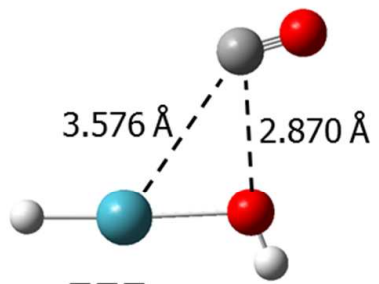

III

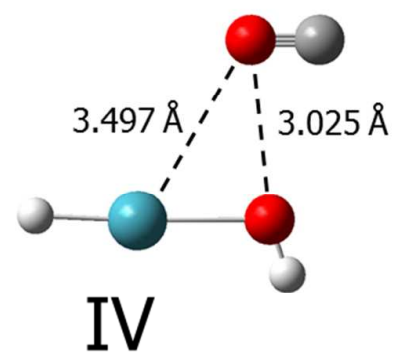

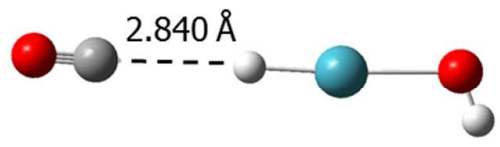

V

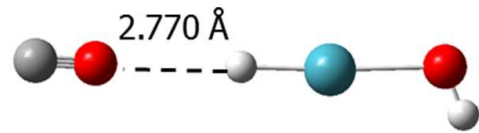

VI

Figure 5. Calculated structures of the $\mathrm{HXeOH} \cdots \mathrm{CO}$ complex. The intermolecular distances are also given. 
Table 2. Distances (in $\AA$ ), angles (in degrees) and relative and interaction energies (in $\mathrm{km} \mathrm{mol}^{-1}$ ) of the monomers and complex structures at the MP2/aug-cc-pVTZ-PP level of theory.

\begin{tabular}{|c|c|c|c|c|c|c|c|}
\hline & Monomers & I & II & III & IV & $\mathrm{V}$ & VI \\
\hline$r(\mathrm{H}-\mathrm{Xe})$ & 1.696 & 1.701 & 1.698 & 1.693 & 1.694 & 1.689 & 1.693 \\
\hline$r(\mathrm{Xe}-\mathrm{O})$ & 2.184 & 2.179 & 2.183 & 2.196 & 2.191 & 2.194 & 2.185 \\
\hline$r(\mathrm{O}-\mathrm{H})$ & 0.968 & 0.969 & 0.968 & 0.968 & 0.968 & 0.967 & 0.967 \\
\hline$r(\mathrm{C}-\mathrm{O})$ & 1.139 & 1.138 & 1.140 & 1.139 & 1.140 & 1.138 & 1.139 \\
\hline$r$ (intermol.) & - & 2.392 & 2.611 & 2.870 & 3.025 & 2.840 & 2.770 \\
\hline$\varphi \mathrm{H}-\mathrm{Xe}-\mathrm{O}$ & 176.7 & 176.8 & 176.9 & 177.4 & 177.1 & 176.7 & 176.7 \\
\hline$\varphi \mathrm{Xe}-\mathrm{O}-\mathrm{H}$ & 109.7 & 108.8 & 108.5 & 109.1 & 109.2 & 110.3 & 110.1 \\
\hline \multirow[t]{4}{*}{$\varphi($ intermol.) } & - & $\mathrm{O}-\mathrm{H} \cdots \mathrm{C}$ & $\mathrm{O}-\mathrm{H} \cdots \mathrm{O}$ & $\mathrm{Xe}-\mathrm{O} \cdots \mathrm{C}$ & $\mathrm{Xe}-\mathrm{O} \cdots \mathrm{O}$ & $\mathrm{Xe}-\mathrm{H} \cdots \mathrm{C}$ & $\mathrm{Xe}-\mathrm{H} \cdots \mathrm{O}$ \\
\hline & & 159.9 & 137.6 & 88.8 & 82.5 & 179.6 & 179.5 \\
\hline & - & $\mathrm{H} \cdots \mathrm{C}-\mathrm{O}$ & $\mathrm{H} \cdots \mathrm{O}-\mathrm{C}$ & $\mathrm{O} \cdots \mathrm{C}-\mathrm{O}$ & $\mathrm{O} \cdots \mathrm{O}-\mathrm{C}$ & $\mathrm{H} \cdots \mathrm{C}-\mathrm{O}$ & $\mathrm{H} \cdots \mathrm{O}-\mathrm{C}$ \\
\hline & & 155.7 & 145.9 & 102.6 & 82.3 & 178.60 & 178.71 \\
\hline$E(\mathrm{rel} .)^{\mathrm{a}}$ & - & +2.83 & +5.53 & 0.0 & +2.57 & +5.66 & +7.49 \\
\hline$E_{\mathrm{BSSE}}^{\mathrm{b}}$ & - & -5.17 & -3.19 & -9.20 & -6.75 & -2.66 & -1.00 \\
\hline
\end{tabular}


${ }^{\text {a }}$ Relative total energy compared to the most stable complex structure III. The values are corrected by the zero point energy differences between the monomer and complex species.

${ }^{\mathrm{b}} \mathrm{BSSE}-\mathrm{corrected}$ interaction energies. 
Table 3. Atomic partial charges (in elementary chargers) calculated by the Mulliken population analysis (Mul) and natural population analysis (NPA) of the monomers and complex structures at the MP2/aug-cc-pVTZ-PP level of theory using the MP2 electron density. The dipole moments $(\mathrm{DM}$, in $\mathrm{D})$ are also given.

\begin{tabular}{|c|c|c|c|c|c|c|c|c|c|c|c|c|c|}
\hline & \multicolumn{2}{|c|}{$q(\mathrm{H})$} & \multicolumn{2}{|c|}{$q(\mathrm{Xe})$} & \multicolumn{2}{|c|}{$q(\mathrm{O})$} & \multicolumn{2}{|c|}{$q(\mathrm{H})$} & \multicolumn{2}{|c|}{$q(\mathrm{C})$} & \multicolumn{2}{|c|}{$q(\mathrm{O})$} & \multirow[t]{2}{*}{$\mathrm{DM}$} \\
\hline & Mul & $\mathrm{NPA}$ & Mul & NPA & Mul & NPA & Mul & $\mathrm{NPA}$ & Mul & NPA & Mul & NPA & \\
\hline Monomers & -0.20 & -0.08 & +0.81 & +0.75 & -0.80 & -1.11 & +0.19 & +0.44 & +0.02 & +0.44 & -0.02 & -0.44 & HXeOH: 3.59 \\
\hline & & & & & & & & & & & & & $\mathrm{CO}: 0.25$ \\
\hline I & -0.21 & -0.09 & +0.82 & +0.75 & -0.84 & -1.11 & +0.25 & +0.45 & +0.06 & +0.43 & -0.09 & -0.43 & 3.17 \\
\hline II & -0.20 & -0.08 & +0.80 & +0.75 & -0.82 & -1.10 & +0.22 & +0.44 & -0.08 & +0.46 & +0.08 & -0.46 & 3.55 \\
\hline III & -0.19 & -0.07 & +0.82 & +0.75 & -0.79 & -1.12 & +0.17 & +0.44 & +0.06 & +0.43 & -0.07 & -0.43 & 3.49 \\
\hline IV & -0.19 & -0.07 & +0.81 & +0.75 & -0.79 & -1.12 & +0.17 & +0.44 & +0.01 & +0.47 & -0.01 & -0.47 & 3.92 \\
\hline $\mathrm{V}$ & -0.27 & -0.06 & +0.93 & +0.74 & -0.81 & -1.12 & +0.19 & +0.44 & +0.06 & +0.43 & -0.08 & -0.43 & 4.41 \\
\hline VI & -0.30 & -0.07 & +0.93 & +0.75 & -0.81 & -1.12 & +0.19 & +0.44 & -0.02 & +0.45 & +0.01 & -0.45 & 3.62 \\
\hline
\end{tabular}


Table 4. Harmonic vibrational frequencies (in $\mathrm{cm}^{-1}$ ) and infrared intensities (in parenthesis, in $\mathrm{km} \mathrm{mol}^{-1}$ ) of the monomers and complex structures at the MP2/aug-cc-pVTZ-PP level of theory.

\begin{tabular}{|c|c|c|c|c|c|c|c|}
\hline & Monomers & $\mathrm{I}$ & II & III & IV & $\mathrm{V}$ & VI \\
\hline OH str. & $3791.3(56)$ & $3776.0(213)$ & $3796.6(59)$ & $3786.9(54)$ & $3790.3(54)$ & $3795.3(52)$ & $3795.1(55)$ \\
\hline CO str. & $2110.0(36)$ & $2117.9(44)$ & $2104.3(50)$ & $2116.1(38)$ & $2106.8(40)$ & $2112.9(46)$ & $2106.9(53)$ \\
\hline HXe str. & $1862.3(958)$ & $1839.0(1082)$ & $1855.0(952)$ & $1872.1(925)$ & $1869.8(916)$ & $1904.2(647)$ & $1886.5(844)$ \\
\hline $\mathrm{H}-\mathrm{O}-\mathrm{Xe}$ bend. & $809.6(3)$ & $858.6(0)$ & $815.5(9)$ & $803.6(1)$ & $809.7(2)$ & $802.8(3)$ & $808.1(3)$ \\
\hline $\mathrm{H}-\mathrm{Xe}-\mathrm{O}$ bend. & $638.6(0)$ & $641.1(0)$ & $638.1(0)$ & $634.6(0)$ & $636.8(0)$ & $661.1(0)$ & $653.3(0)$ \\
\hline $\mathrm{H}-\mathrm{Xe}-\mathrm{O}$ bend. & $583.3(7)$ & $606.4(9)$ & $586.9(6)$ & $578.8(8)$ & $583.7(7)$ & $588.8(9)$ & $588.8(9)$ \\
\hline \multirow[t]{2}{*}{$\mathrm{XeO}$ str. } & $447.4(152)$ & $453.2(157)$ & $447.9(150)$ & $439.2(150)$ & $442.7(150)$ & $441.1(176)$ & $446.9(172)$ \\
\hline & - & $312.5(55)$ & $126.2(68)$ & $138.5(2)$ & $136.6(94)$ & $43.4(1)$ & $37.2(0)$ \\
\hline Intermolecular & - & $106.8(1)$ & $68.1(2)$ & $110.7(90)$ & $103.8(3)$ & $39.5(1)$ & $27.5(0)$ \\
\hline \multirow[t]{3}{*}{ modes } & - & $51.9(0)$ & $37.4(1)$ & $82.2(6)$ & $71.1(3)$ & $39.1(2)$ & $27.4(1)$ \\
\hline & - & $31.8(2)$ & $24.1(2)$ & $62.1(4)$ & $48.01(2)$ & $22.5(0)$ & $17.0(0)$ \\
\hline & - & $5.3(6)$ & $11.3(9)$ & $56.2(6)$ & $31.7(1)$ & $21.5(5)$ & $16.8(6)$ \\
\hline
\end{tabular}


Table 5. Harmonic and anharmonic vibrational shifts (in $\mathrm{cm}^{-1}$ ) upon complexation of the monomers and complex structures at the MP2/aug-ccpVTZ-PP level of theory.

\begin{tabular}{|c|c|c|c|c|c|c|c|c|c|c|c|c|}
\hline \multirow[t]{2}{*}{ Mode } & \multicolumn{3}{|c|}{ I } & \multicolumn{2}{|l|}{ II } & \multicolumn{2}{|l|}{ III } & \multicolumn{2}{|l|}{ IV } & \multicolumn{2}{|l|}{ V } & VI \\
\hline & Harm. & Anharm. & Harm. & Anharm. & Harm. & Anharm. & Harm. & Anharm. & Harm. & Anharm. & Harm. & Anharm. \\
\hline $\mathrm{OH}$ str. & -15.3 & -4.6 & +5.3 & -3.6 & -4.4 & -5.1 & -1.0 & -2.8 & +4.0 & -13.5 & +3.8 & -12.3 \\
\hline CO str. & +8.0 & +3.3 & -5.7 & +0.7 & +6.1 & +3.0 & -3.2 & -5.7 & +2.9 & +36.7 & -3.1 & +50.4 \\
\hline HXe str. & -23.3 & -6.6 & -7.4 & -0.8 & +9.8 & +7.4 & +7.5 & +4.5 & +41.8 & +25.6 & +24.2 & +15.6 \\
\hline $\mathrm{H}-\mathrm{O}-\mathrm{Xe}$ bend. & +48.9 & -11.9 & +5.9 & -8.8 & -6.0 & -15.4 & +0.1 & -4.0 & -6.9 & -7.6 & -1.6 & +1.6 \\
\hline $\mathrm{H}-\mathrm{Xe}-\mathrm{O}$ bend. & +2.5 & -17.2 & -0.5 & -22.8 & -4.0 & -37.0 & -1.8 & -27.3 & +22.6 & +1.6 & +14.7 & +3.8 \\
\hline $\mathrm{H}-\mathrm{Xe}-\mathrm{O}$ bend. & +23.0 & +6.9 & +3.6 & -13.5 & -4.5 & -16.3 & +0.4 & -16.3 & +5.5 & -3.7 & +5.5 & +1.5 \\
\hline $\mathrm{XeO}$ str. & +5.8 & +2.4 & +0.6 & -3.8 & -8.2 & -6.9 & -4.6 & -6.9 & -6.3 & +7.3 & -0.4 & +13.3 \\
\hline
\end{tabular}




\section{CONCLUDING DISCUSSION}

In the present work, we have identified a complex of a noble-gas hydride $\mathrm{HXeOH}$ with carbon monoxide. This species is prepared by the annealing-induced reaction of mobile $\mathrm{H}$ atoms with the $\mathrm{OH} \cdots \mathrm{CO}$ complexes in a xenon matrix. The $\mathrm{OH} \cdots \mathrm{CO}$ complexes are produced by VUV photolysis of the $\mathrm{H}_{2} \mathrm{O} \cdots \mathrm{CO}$ complexes, preferably with the $\mathrm{HOH} \cdots \mathrm{CO}$ structure rather than with the $\mathrm{HOH}^{\cdots}$ OC structure. The $\mathrm{H}_{2} \mathrm{O} \cdots \mathrm{CO}$ complexes can be made by UV photolysis of formic acid in a xenon matrix or by direct deposition of $\mathrm{H}_{2} \mathrm{O} / \mathrm{CO} / \mathrm{Xe}$ mixture. The known noble-has hydrides $\mathrm{HXeOH}, \mathrm{HXeO}, \mathrm{HXeOXeH}$, and $\mathrm{HXeH}$ in the monomeric forms are also observed after annealing. The $\mathrm{H}-\mathrm{Xe}$ stretching mode of the $\mathrm{HXeOH}{ }^{\cdots} \mathrm{CO}$ complex absorbs at $1590.3 \mathrm{~cm}^{-1}$ and it is blueshifted by $12.7 \mathrm{~cm}^{-1}$ from the $\mathrm{H}-\mathrm{Xe}$ stretching band of $\mathrm{HXeOH}$ monomer. The observed blue shift indicates the stabilization of the $\mathrm{H}-\mathrm{Xe}$ bond upon complexation, which is characteristic of complexes of noble-gas hydrides. ${ }^{18}$ The $\mathrm{HXeOH} \cdots \mathrm{CO}$ species is the first complex of a noble-gas hydride with carbon monoxide and the second complex of an interesting species $\mathrm{HXeOH}$ (after the $\mathrm{HXeOH} \cdots \mathrm{H}_{2} \mathrm{O}$ complex). ${ }^{20}$ The spectral effect of $\mathrm{CO}$ on $\mathrm{HXeOH}$ is similar to that of $\mathrm{N}_{2}$ on $\mathrm{HXeY}$ $(\mathrm{Y}=\mathrm{Cl} \text { and } \mathrm{Br})^{23}$

Now, we discuss the structural assignment of the experimental complex based on the ab initio calculations. It is clear that it cannot have structures I and II with the red-shifted H-Xe stretching modes. Indeed, no H-Xe stretching bands with red shifts are observed in the experimental spectra. Structures V and VI are also improbable to be formed in experiment because they have very weak interaction and significantly larger changes of the H-Xe stretching frequency (harmonic shifts +41.8 and $\left.+24.2 \mathrm{~cm}^{-1}\right)$ than the experimental value $\left(+12.7 \mathrm{~cm}^{-1}\right)$. Moreover, these structures are formed from the $\mathrm{OH}$ and $\mathrm{CO}$ fragments locating in neighboring cages but not from the $\mathrm{OH} \cdots \mathrm{CO}$ complexes. On the other hand, structures III and IV are both suitable for the experimental complex. We propose that structure III is the most probable candidate for the experimental species. The $\mathrm{HXeOH}^{\cdots} \mathrm{CO}$ complex is formed from the $\mathrm{OH} \cdots \mathrm{CO}$ complex, in which the hydrogen atom 
interacts with the carbon atom. In this situation, structure I probably forms first upon annealing and then reorganizes to a more stable structure. It is plausible that this reorganization leads to the most stable structure III. The calculated shift of the H-Xe stretching mode of structure III is slightly closer to the experimental value $\left(9.8\right.$ vs. $\left.12.7 \mathrm{~cm}^{-1}\right)$ than that of structure IV $\left(7.5 \mathrm{~cm}^{-1}\right)$ even though it is not a strong argument.

The mechanism of the formation of the $\mathrm{HXeOH} \cdots \mathrm{CO}$ complex is not straightforward because of the decomposition of the $\mathrm{OH} \cdots \mathrm{CO}$ complex above $30 \mathrm{~K}$ (producing $\mathrm{HOCO}$ ). In fact, this decomposition explains why after annealing at $45 \mathrm{~K}$, the amount of the $\mathrm{HXeOH} \cdots \mathrm{CO}$ complexes is much smaller than the amount of the $\mathrm{HXeOH}$ monomers, whereas the amounts of the $\mathrm{OH} \cdots \mathrm{CO}$ complexes and $\mathrm{OH}$ monomers before annealing are comparable. Three mechanisms can be suggested for the $\mathrm{HXeOH}^{\cdots} \mathrm{CO}$ formation. First, some part of hydrogen atoms locate after photolysis in the vicinity of the $\mathrm{OH} \cdots \mathrm{CO}$ complexes, and these atoms can locally move and form the $\mathrm{HXeOH} \cdots \mathrm{CO}$ complexes at temperatures below $30 \mathrm{~K}$. This local process is indicated by formation of the $\mathrm{HXeOH} \cdots \mathrm{CO}$ complexes and $\mathrm{HXeOH}$ monomers after annealing at $27 \mathrm{~K}$ (spectrum $\mathrm{d}$ in Figure 4). It is remarkable that the amounts of the $\mathrm{HXeOH} \cdots \mathrm{CO}$ complexes and $\mathrm{HXeOH}$ monomers are comparable after this "low-temperature" annealing. Second, a small part of the $\mathrm{OH}^{\cdots} \mathrm{CO}$ complexes can be still present in the matrix above $35 \mathrm{~K}$, which increases the amount of the $\mathrm{HXeOH} \cdots \mathrm{CO}$ complexes. At the higher temperatures, the formation of $\mathrm{HXeOH}$ monomers is more efficient than that of the $\mathrm{HXeOH}^{\cdots} \mathrm{CO}$ complexes. Third, the thermal mobility of $\mathrm{CO}$ molecules can also lead to the $\mathrm{HXeOH} \cdots \mathrm{CO}$ complexes due to their attachment to $\mathrm{HXeOH}$ monomers. To recall, the formation of the complexes of some noble-gas hydrides with acetylene occurs due to thermal mobilization of acetylene. ${ }^{24,50}$

\section{ASSOCIATED CONTENT}


Supplementary Material. Calculated coordinates and anharmonic spectra of the $\mathrm{HXeOH}$ and $\mathrm{CO}$ monomers and of the structures of the $\mathrm{HXeOH} \cdots \mathrm{CO}$ complex.

\section{AUTHOR INFORMATION}

\section{Corresponding Author}

E-mail: leonid.khriachtchev@,helsinki.fi.

\section{ACKNOWLEDGMENT}

This work was supported by the Academy of Finland (Projects No. 1277993 and No. 1288889). The CSC-IT Center for Science is thanked for computational resources.

\section{REFERENCES}

(1) Bartlett, N. Xenon hexafluoroplatinate (V) Xe ${ }^{+}[\mathrm{PtF} 6]^{-}$. Proc. Chem. Soc. 1962, 218.

(2) Brel, V. K.; Pirguliyev, N. S.; Zefirov, N. S. Chemistry of Xenon Derivatives. Synthesis and Chemical Properties. Usp. Khim. 2001, 70, 262-298.

(3) Lehmann, J. F.; Mercier, H. P. A.; Schrobilgen, G. J. The Chemistry of Krypton. Coord. Chem. Rev. 2002, 233, 1-39.

(4) Grochala, W.; Khriachtchev, L.; Räsänen, M. Noble-Gas Chemistry. In Physics and Chemistry at Low Temperatures, edited by L. Khriachtchev (Pan Stanford Publishing, Singapore, 2011), Chapter 13, pp. 419-446.

(5) Haner J.; Schrobilgen, G. J. The Chemistry of Xenon(IV). Chem. Rev. 2015, 115, 1255-1295.

(6) Turner, J.; Pimentel, G. C. Krypton Fluoride: Preparation by the Matrix Isolation Technique. Science 1963, 140, 974-975. 
(7) Howard, W. F.: Andrews, L. Synthesis of Noble-Gas Dihalides by Laser Photolysis of MatrixIsolated Halogens. J. Am. Chem. Soc. 1974, 96, 7864-7868.

(8) Lundell, J.; Khriachtchev, L.; Pettersson, M.; Räsänen, M. Formation and Characterization of Neutral Krypton and Xenon Hydrides. Low Temp. Phys. 2000, 26, 680-690.

(9) Khriachtchev, L.; Räsänen, M.; Gerber, R. B. Noble-Gas Hydrides: New Chemistry at Low Temperatures. Acc. Chem. Res. 2009, 42, 183-191.

(10) Khriachtchev, L.; Pettersson, M.; Runeberg, N.; Lundell, J.; Räsänen, M. A Stable Argon Compound. Nature (London) 2000, 406, 874-876.

(11) Khriachtchev, L.; Pettersson, M.; Lignell, A.; Räsänen, M. A More Stable Configuration of HArF in Solid Argon. J. Am. Chem. Soc. 2001, 123, 8610-8611.

(12) Khriachtchev, L.; Tanskanen, H.; Cohen, A.; Gerber, R. B.; Lundell, J.; Pettersson, M.;

Kiljunen, H.; Räsänen, M. A Gate to Organokrypton Chemistry: HKrCCH. J. Am. Chem. Soc. 2003, 125, 6876-6877.

(13) Zhu, C.; Khriachtchev, L.; Räsänen, M. Matrix-Isolation and Ab Initio Study of HKrCCCl and HXeCCCl. J. Chem. Phys. 2015, 143, 244319.

(14) Duarte, L.; Khriachtchev, L. An Aromatic Noble-Gas Hydride: $\mathrm{C}_{6} \mathrm{H}_{5} \mathrm{CCXeH}$. Sci. Rep. 2017, $7,3130$.

(15) Pettersson, M.; Khriachtchev, L.; Lundell, J.; Räsänen, M. A Chemical Compound Formed from Water and Xenon: HXeOH. J. Am. Chem. Soc. 1999, 121, 11904-11905.

(16) Pettersson, M.; Khriachtchev, L.; Jolkkonen, S.; Lundell, J.; Räsänen, M. Photochemistry of HNCO in Solid Xenon: Photoinduced and Thermally Activated Formation of HXeNCO. J. Phys. Chem. A 2000, 104, 3579-3583. 
(17) Khriachtchev, L.; Pettersson, M.; Lundell, J.; Räsänen, M. Intermediate Reactions in SolidState Photolysis. J. Chem. Phys. 2001, 114, 7727-7730.

(18) Lignell, A.; Khriachtchev, L. Intermolecular Interactions Involving Noble-Gas Hydrides: Where the Blue Shift of Vibrational Frequency is a Normal Effect. J. Mol. Struct. 2008, 889, 1-11.

(19) Khriachtchev, L. Matrix-Isolation Studies of Noncovalent Interactions: More Sophisticated Approaches. J. Phys. Chem. A 2015, 119, 2735-2746.

(20) Nemukhin, A. V.; Grigorenko, B. L.; Khriachtchev, L.; Tanskanen, H.; Pettersson, M.; Räsänen, M. Intermolecular Complexes of $\mathrm{HXeOH}$ with Water: Stabilization and Destabilization Effects. J. Am. Chem. Soc. 2002, 124, 10706-10711.

(21) Lignell, A.; Lundell, J.; Khriachtchev, L.; Räsänen, M. Experimental and Computational Study of $\mathrm{HXeY} \cdots \mathrm{HX}$ Complexes $(\mathrm{X}, \mathrm{Y}=\mathrm{Cl}$ and $\mathrm{Br}$ ): An Example of Exceptionally Large Complexation Effect. J. Phys. Chem. A 2008, 112, 5486-5494.

(22) Corani, A.; Domanskaya, A.; Khriachtchev, L.; Räsänen, M.; Lignell, A. Matrix-Isolation and

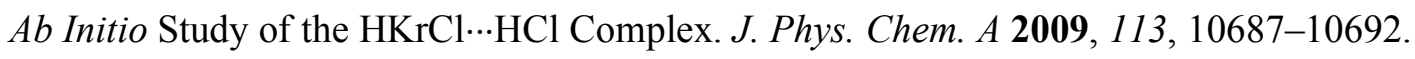

(23) Khriachtchev, L.; Tapio, S.; Räsänen, M.; Domanskaya, A.; Lignell, A. HY $\cdots \mathrm{N}_{2}$ and $\mathrm{HXeY} \cdots \mathrm{N}_{2}$ Complexes in Solid Xenon ( $\mathrm{Y}=\mathrm{Cl}$ and $\left.\mathrm{Br}\right)$ : Unexpected Suppression of the Complex Formation for Deposition at Higher Temperature. J. Chem. Phys. 2010, 133, 084309.

(24) Domanskaya, A.; Kobzarenko, A. V.; Tsivion, E.; Khriachtchev, L.; Feldman, V. I.; Gerber, R. B.; Räsänen, M. Matrix-Isolation and Ab Initio Study of HXeCCH Complexed with Acetylene. Chem. Phys. Lett. 2009, 481, 83-87.

(25) Alkorta, I.; Elguero, J. Hydrogen Bonding Properties of Krypton Derivatives. Chem. Phys. Lett. 2003, 381, 505-511. 
(26) McDowell, S. A. C. Blue Shifting and Red Shifting Hydrogen Bonds: A Study of the HArF $\cdots \mathrm{N}_{2}$ and HArF $\cdots \mathrm{P}_{2}$ Complexes. Phys. Chem. Chem. Phys. 2003, 5, 808-811.

(27) Yen, S. Y.; Mou, C. H.; Hu, W. P. Strong Hydrogen Bonding between Neutral Noble-Gas Molecules $(\mathrm{HNgF}, \mathrm{Ng}=\mathrm{Ar}, \mathrm{Kr}$, and $\mathrm{Xe})$ and Hydrogen Fluoride: A Theoretical Study. Chem. Phys. Lett. 2004, 383, 606-611.

(28) McDowell, S. A. C.; Buckingham, A. D. Comparison of Some Vibrational Features of $\mathrm{FArH} \cdots \mathrm{Rg}$ and $\mathrm{FH} \cdots \mathrm{Rg}$ Complexes $(\mathrm{Rg}=\mathrm{He}, \mathrm{Ne}, \mathrm{Ar}, \mathrm{Kr})$. Spectrochim. Acta A Mol. Biomol. Spectrosc. 2005, 61, 1603-1609.

(29) McDowell, S. A. C. Studies of Neutral Rare-Gas Compounds and their Non-Covalent Interactions with Other Molecules. Curr. Org. Chem. 2006, 10, 791-803.

(30) Cukras, J.; Sadlej, J. Symmetry-Adapted Perturbation Theory Interaction Energy Decomposition for Some Noble Gas Complexes. Chem. Phys. Lett. 2008, 459, 44-48.

(31) Cukras, J.; Sadlej, J. Theoretical Predictions of the Spectroscopic Parameters in Noble-Gas Molecules: $\mathrm{HXeOH}$ and its Complex with Water. Phys. Chem. Chem. Phys. 2011, 13, 1545515467.

(32) Li, Q. Z.; Zhao, J. L.; Jing, B.; Li, R.; Li, W. Z.; Cheng, J. B. The Structure, Properties, and Nature of HArF-HOX (X = F, Cl, Br) Complex: An Ab Initio Study and an Unusual Short Hydrogen Bond. J. Comput. Chem. 2011, 32, 2432-2440.

(33) Jankowska, J.; Sadlej, J. Spectroscopic Parameters in Noble Gas Molecule: HXeF and Its Complex with HF. Chem. Phys. Lett. 2011, 517, 155-161.

(34) Esrafili, M. D.; Shahabivand, S.; Vessally, E. HRgCN and $\mathrm{HRgNC}$ as Halogen Bond Acceptors $(\mathrm{Rg}=\mathrm{Kr}$ and $\mathrm{Xe})$ : A Theoretical Study upon Strength and Nature of Halogen $\cdots$ Nitrogen and Halogen ‥Carbon Interactions. Comput. Theor. Chem. 2013, 1020, 1-6. 
(35) Ma, L.; Huang, Z.; Niu, X.; Shen, T.; Guo, L. A Theoretical Study on the Hydrogen Bonding Interactions in $\mathrm{HXeCCH} \cdots \mathrm{Y}\left(\mathrm{Y}=\mathrm{H}_{2} \mathrm{O}\right.$ and $\left.\mathrm{HF}\right)$ Complexes. Comput. Theor. Chem. 2013, 1017, $14-21$.

(36) Mondal, S.; Singh, P. C. Noble Gas Induced Surprisingly Higher Stability of $\pi$ Hydrogen Bonded Complex: Comparative Study of Hydrogen Bonded Complexes of $\mathrm{HKrCCH}$ and $\mathrm{HCCH}$ with $\mathrm{H}_{2} \mathrm{O}, \mathrm{NH}_{3}, \mathrm{CH}_{3} \mathrm{OH}$ and $\mathrm{CH}_{3} \mathrm{NH}_{2}$. RSC Adv. 2014, 4, 20752-20760.

(37) Cohen, A.; Tsuge, M.; Khriachtchev, L.; Räsänen, M.; Gerber. R. B. Modeling of HXeBr in $\mathrm{CO}_{2}$ and Xe Environments: Structure, Energetics and Vibrational Spectra. Chem. Phys. Lett. 2014, 594, 18-22.

(38) Esrafili, M. D.; Juyban, P.; Solimannejad, M. Exploring Lithium Bonding Interactions between Noble-Gas Hydrides HXeY and LiX Molecules $\left(\mathrm{Y}=\mathrm{H}, \mathrm{CN}, \mathrm{NC}\right.$ and $\mathrm{X}=\mathrm{H}, \mathrm{CN}, \mathrm{NC}, \mathrm{OH}, \mathrm{NH}_{2}$, $\mathrm{CH}_{3}$ ): A Theoretical Study. Comput. Theor. Chem. 2014, 1027, 84-90.

(39) McDowell, S. A. C.; Fiedler, C. S. A Computational Study of Beryllium-Bonded $\mathrm{H}_{2} \mathrm{Be} \cdots \mathrm{FNgH} / \mathrm{FKrCl}(\mathrm{Ng}=\mathrm{Ar}, \mathrm{Kr})$ Dyads and Their Intermolecular Interactions with the Model Nucleophiles $\mathrm{F}^{-}, \mathrm{NH}_{3}$ and NCH. Comput. Theor. Chem. 2016, 1084, 150-156.

(40) Ryazantsev, S. V.; Duarte, L.; Feldman, V. I.; Khriachtchev, L. VUV Photochemistry of the $\mathrm{H}_{2} \mathrm{O} \cdots \mathrm{CO}$ Complex in Noble-Gas Matrices: Formation of the $\mathrm{OH} \cdots \mathrm{CO}$ Complex and the HOCO Radical. Phys. Chem. Chem. Phys. 2017, 19, 356-365.

(41) Eberlein, J.; Creuzburg, M. Mobility of Atomic Hydrogen in Solid Krypton and Xenon. J. Chem. Phys. 1997, 106, 2188-2194.

(42) Khriachtchev, L.; Tanskanen, H.; Pettersson, M.; Räsänen, M.; Feldman, V.; Sukhov, F.; Orlov, A.; Shestakov, A. F. Isotopic Effect on Thermal Mobility of Atomic Hydrogen in Solid Xenon J. Chem. Phys. 2002, 116, 5708-5716. 
(43) Lundell, J.; Räsänen, M. The 193-nm Induced Photodecomposition of HCOOH in Rare-Gas Matrices: The $\mathrm{H}_{2} \mathrm{O}-\mathrm{CO}$ 1:1 Complex. J. Phys. Chem. 1995, 99, 14301-14308.

(44) Kunttu, H.; Seetula, J.; Räsänen, M.; Apkarian, V. A. Photogeneration of Ions via Delocalized Charge Transfer States. I. $\mathrm{Xe}_{2} \mathrm{H}^{+}$and $\mathrm{Xe}_{2} \mathrm{D}^{+}$in Solid Xe. J. Chem. Phys. 1992, 96, 5630-5635.

(45) Cao, Q; Berski, S; Räsänen, M.; Latajka, Z.; Khriachtchev, L. Spectroscopic and Computational Characterization of the $\mathrm{HCO} \cdots \mathrm{H}_{2} \mathrm{O}$ Complex. J. Phys. Chem. A 2013, 117, 43854393.

(46) Cao, Q.; Berski, S.; Latajka, Z.; Räsänen, M.; Khriachtchev, L. Reaction of Atomic Hydrogen with Formic Acid. Phys. Chem. Chem. Phys. 2014, 16, 5993-6001.

(47) Khriachtchev, L.; Pettersson, M.; Lundell, J.; Tanskanen, H.; Kiviniemi, T.; Runeberg, N.; Räsänen, M. A Neutral Xenon-Containing Radical, HXeO. J. Am. Chem. Soc. 2003, 125, 1454 1455.

(48) Khriachtchev, L.; Isokoski, K.; Cohen, A.; Räsänen, M.; R. B. Gerber. A Small Neutral Molecule with Two Noble-Gas Atoms: HXeOXeH. J. Am. Chem. Soc. 2008, 130, 6114-6118.

(49) Pettersson, M.; Lundell, J.; Räsänen, M. Neutral Rare-Gas Containing Charge-Transfer Molecules in Solid Matrices. 2. HXeH, HXeD, and DXeD in Xe J. Chem. Phys. 1995, 103, 205210.

(50) Willmann, K.; Vent-Schmidt, T.; Räsänen, M.; Riedel, S.; Khriachtchev, L. Matrix-Isolation and Computational Study of the HKrCCH $\cdots$ HCCH Complex. RSC Adv. 2015, 5, 35783-35791.

(51) Duarte, L.; Khriachtchev, L. Matrix-Isolation and Computational Study of the HXeCCXeH $\cdots \mathrm{HCCH}$ and $\mathrm{HXeCC} \cdots \mathrm{HCCH}$ Complexes. RSC Adv. 2017, 7, 813-820. 
(52) Frisch, M. J.; Trucks, G. W.; Schlegel, H. B.; Scuseria, G. E.; Robb, M. A.; Cheeseman, J. R.; Scalmani, G.; Barone, V.; Mennucci, B.; Petersson, G. A.; et al. Gaussian 09, Revision E.01; Gaussian, Inc.: Wallingford, CT, 2013.

(53) C. Møller, C.; Plesset, M. S. Note on an Approximation Treatment for Many-electron Systems, Phys. Rev. 1934, 46, 618-622.

(54) Frisch, M. J.; Head-Gordon, M.; Pople, J. A. Direct MP2 Gradient Method. Chem. Phys. Lett. 1990, 166, 275-280.

(55) Peterson, K. A.; Figgen, D.; Goll, E.; Stoll, H.; Dolg, M. Systematically Convergent Basis Sets with Relativistic Pseudopotentials. II. Small-core Pseudopotentials and Correlation Consistent Basis Sets for the Post-d Group 16-18 Elements. J. Chem. Phys. 2003, 119, 11113-11123.

(56) Schuchardt, K. L.; Didier, B. T.; Elsethagen, T.; Sun, L.; Gurumoorthi, V.; Chase, J.; Li, J.; Windus, T. L. Basis Set Exchange: A Community Database for Computational Sciences. J. Chem. Inf. Model., 2007, 47, 1045-1052.

(57) Dunning, T. H., Jr. Gaussian Basis Sets for Use in Correlated Molecular Calculations. I. The Atoms Boron through Neon and Hydrogen. J. Chem. Phys. 1989, 90, 1007-1023.

(58) Kendall, R. A.; Dunning, T. H., Jr.; Harrison, R. J. Electron Affinities of the First-row Atoms Revisited. Systematic Basis Sets and Wave Functions. J. Chem. Phys. 1992, 96, 6796-6806. (59) Foster, J. P.; Weinhold, F. Natural Hybrid Orbitals. J. Am. Chem. Soc. 1980, 102, 7211-7218.

(60) Barone, V. Vibrational Zero-Point Energies and Thermodynamic Functions beyond the Harmonic Approximation. J. Chem. Phys. 2004, 120, 3059-3065.

(61) Bloino, J.; Barone, V. A Second-order Perturbation Theory Route to Vibrational Averages and Transition Properties of Molecules: General Formulation and Application to Infrared and Vibrational Circular Dichroism Spectroscopies. J. Chem. Phys. 2012, 136, 124108. 
(62) Boys, S. F.; Bernardi, F. Calculation of Small Molecular Interactions by Differences of Separate Total Energies Some Procedures with Reduced Errors. Mol. Phys. 1970, 19, 553-566.

(63) Khriachtchev, L.; Lignell, A.; Juselius, J.; Räsänen, M.; Savchenko, E. Infrared Absorption Spectrum of Matrix-Isolated Noble-Gas Hydride Molecules: Fingerprints of Specific Interactions and Hindered Rotation. J. Chem. Phys. 2005, 122, 014510. 
Table of Contents Graphic

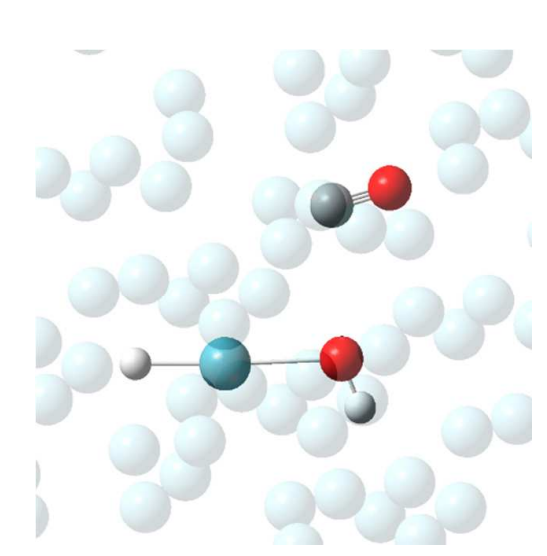

17

18

19

20

21

22

23

24

25

26

27

28

29

30

31

32

33

34

35

36

37

38

39

40

41

42

43

44

45

46

47

48

49

50

51

52

53

54

55

56

57

58

59

60 